\title{
Impact of COVID 19 webinar on knowledge, attitude and practices among Indian population- A community based study
}

\author{
Vijayashree Mathad ${ }^{a, *}$, Annupama Shetty ${ }^{\mathrm{b}}$ \\ ${ }^{a}$ Consultant, Narayana Health CSR, Bangalore, India \\ ${ }^{\mathrm{b}}$ Mission Director, Biocon Foundation, Bangalore, India
}

\section{A R T I C L E I N F O}

\section{Keywords:}

COVID 19

Pre test

Post test

Safety recommendation

Virtual training

Webinar

\begin{abstract}
A B S T R A C T
Introduction: The present study focuses on virtually training people from various back ground on knowledge, attitude and practices for COVID appropriate behavior as well as to assess the impact of training so as to provide recommendation to behavior and policy amendments.

Method: Narayana Health CSR conducted 269 sessions for 15,620 Participants across India in 7 languages during April to October 2020. The participants were instructed to fill the Pre test KAP COVID 19 awareness Google form after obtaining the informed consent. The participants were then provided with detailed and updated webinar on COVID 19 awareness followed by Post test COVID 19 awareness Google form. The study included only the participants who completed both pre and post test survey through Google forms which comprise of 2726 individuals.

Results: Among 2726 individuals majority were male (59\%) from rural areas(52\%) in the age group of 28-37yrs (39\%) followed by 18-27 yrs (24\%). As per the education of the participants majority were graduates/diploma holders (43\%) and salaried employees(59\%). The mean pre and post test score of all participants at $95 \%$ confidence level was $29.26 \pm 3.78$ and $33.78 \pm 4.12$ respectively. The difference between the mean of pre and post test was significantly associated among various groups based on gender, Karnataka, rural and urban, government and salaried, living conditions as well.

Conclusion: The virtual training had a significant impact on knowledge among individuals. We recommend promoting health literacy especially among teachers and migrant population as to create awareness and stop the spread of infection.
\end{abstract}

\section{Introduction}

Corona Virus Disease (COVID 19) is a highly infectious disease originated in Wuhan, China caused by SARS-CoV2(Severe Acute Respiratory Syndrome Corona virus 2). ${ }^{1}$ World Health Organization(WHO) declared COVID 19 pandemic on march $11,2020 .^{2}$ The disease has now engulfed the globe affecting 216 countries, areas and territories. Many of the countries globally are facing second surge in Covid cases. Globally the numbers of daily rise in cases have reached a peak of over 800,000 and daily death as high as10000. ${ }^{3}$ Mode of transmission for covid 19 as per the research data is mainly droplet followed by fomites and under certain circumstances its air borne.

COVID 19 is evolving science and lot of research are ongoing on in terms of characteristics of virus and treatment. Hence prevention plays a major role to combat the spread of infection. This can be achieved by mass education using virtual methods. The golden rules to fight against the spread of infection are frequent hand hygiene, respiratory and mask etiquette, social distancing. Although $80-90 \%$ COVID positive are mild and can be managed with home isolation still it's not possible due to poor housing condition in a densely populated country like India. Mild and asymptomatic cases in the community remain undiagnosed and act as a super spreader affecting a wide majority of susceptible and vulnerable population.

In view of COVID 19 India went into nationwide lockdown from March 24, 2020 for a period of 21 days limiting the movement of entire 138 crore populations to combat the spread of disease. ${ }^{5}$ India had a series of 4 lockdowns and 6 unlock phases before coming back to normalcy. The rise in cases was associated with various myths, anxiety

; COVID, Corona Virus Disease.

* Corresponding author.

E-mail address: vijayashreemathad@yahoo.in (V. Mathad). 
and info dynamics. People had less access to genuine source of information and were enveloped with misleading information from Whatsapp University. The attitude of Indian population is more social hence a practice of physical distance is a challenge. Hence the best way to address the issue is to educate the mass regarding characteristics of disease. Hence, this study was undertaken with the objective to provide virtual training to the susceptible population regarding COVID safety recommendations focusing on life after lockdown.

\section{Methodology}

The population comprised of teachers who were involved in contact tracing, factory employees before resuming the work, NGO's involved in distribution of aids, educational institutes and self help groups across India. The participants were administered pre test Google form after obtaining informed consent to assess the baseline knowledge, attitude and practices related to COVID 19 appropriate behavior. Virtual training were conducted by organizing 269 webinars in 7 different languages across India. The knowledge score was assessed by using the post test Google form. This was descriptive questionnaire had 35 items comprising of 7 sections which consisted of Demographic profile followed by 12 questions which explored Knowledge, 10 questions that were focused on Attitude and 6 questions addressed on Practices related to Covid-19. Respondents have to answer the questions in checkbox, dropdown and multiple choices as per the format.

Internal consistency will be assessed using cronbach's alpha test $(\alpha=$ 0.7 ) for acceptability after doing a pilot study among 30 participants.

\subsection{Study design}

This was a descriptive questionnaire based community study to assess the impact of health literacy among people of India during COVID 19 pandemic. The study was carried out by Narayana health CSR team spread across India during March 2020 to September 2020. A total of 269 sessions were conducted in seven different local languages so as to increase the level of health literacy among the people. The target population were 100 per session hence the target population was 26,900 . The team was able to reach 15,620 participants. One representative per 10 individual filled the questionnaire. Hence the sample size required was 2690 adding $10 \%$ attrition rate 2959 sample sizes was calculated. We analyzed 2726 individuals who had completed both pre and post test survey. The pretest and post test data was collected using google forms after obtaining informed consent and those who were not able to fill the Google form, the test was taken by the field executive through tele surveys. The study participants were from Karnataka, Maharashtra, Gujarat, Delhi, Howrah, Tamil Nadu, Bihar and Uttar Pradesh.

Inclusion criteria: All the participants who were willing to attend COVID 19 webinar organized by NH-CSR and participated in both pre and post test. Exclusion criteria were participants who did not take the post test after the webinar.

The Pre designed and tested validated questionnaire was used in the study which was based on the literature available at the reliable sources. Pre test and Post test questionnaire had same 35 items comprising of 7 sections which consisted of Demographic profile followed by 12 questions which explored Knowledge, 10 questions that were focused on Attitude and 6 questions addressed on Practices related to Covid-19. The assessment was through the negative and positive impact associated with COVID 19. These scales utilized the five point Likerts scale ranging from strongly disagree ( 1 point) to strongly agree (5 points). Respondents had to answer the questions in checkbox, dropdown and multiple choice as per the format. The study participants were factory employees, general public registered by NGO working in those areas, government and private school teachers, students and self help group members.

The resource persons were panel of public health experts from Narayana Health CSR. The covid 19 webinars consisted of latest statistical updates and training materials from the reliable sites such as WHO (World health Organization), Mohfw (Ministry of Health and Family Welfare), ICMR (Indian Council for Medical Research), CDC(Center for Disease Control) and covid19india. ${ }^{6-10}$ All the webinars were in local languages as to ease the understanding for general public and for capacity building so as to prevent the spread of infection as well as stigma associated with the pandemic. All the participants were informed to take pretest prior to webinar and post test was taken after the completion of webinar.

The topics in the webinar consisted of origin of disease, present situation, causative agent, modes of transmission, methods of prevention, basic precautions at personal, household and community level, hand washing techniques, respiratory etiquette, disinfections, types and methods of mask usage, importance of social distancing, safety recommendation for vulnerable population, symptoms, diagnosis, where and whom to contact, Protocol for covid treatment, strategy for Covid testing in India, covid appropriate behaviors, nutrition during covid as well as myth busters followed by 30 min discussions.

\subsection{Statistical analysis}

Descriptive statistics was used to assess the demographic characteristics. Categorical variables was assessed in percentage while continuous variable was assessed as Mean \pm SD. Inferential statistics like MannWhitney $U$ test and Kruskal Walis tests were used to assess the difference, while Spearman's rank correlation coefficient were used to evaluate the relationship between the study variables. A p value of $<0.05$ was taken as significant. Chi square test and $\mathrm{p}$ value was used to assess the demographic association. Correlation between knowledge, attitude and practices were assessed using the criteria $0-0.25$ as weak correlation, $0.26-0.5$ as fair correlation while $0.6-0.75$ as good and greater than 0.76 as excellent correlation. Each positive practice was given as 1 score and negative as 0 score. Score $>9$ was considered as positive practices. The mean positive practice will be presented as Mean \pm SD.

\section{Results}

The demographic profile comprising of 7 questions are displayed in percentage form and Mean \pm SD. The Knowledge, Attitude and practice sections comprised of 35 questions consisting of symptoms, transmission, preventions and myths with the maximum score of 43 . The score of 20 was considered adequate. The average score in each section was presented as mean \pm SD scores.

Among 2726 individuals who had taken pre and post test were majority were male (59\%) with majority from rural areas (52\%). Majority were in age group of $28-37$ yrs (39\%) followed by $18-27$ yrs (24\%), $48-57 y r s(12 \%)$ and remaining above 57 years. As per the education of the participants majority were graduates/diploma holders (43\%) followed by post graduates (38\%). Majority of the participants were salaried employees (59\%) followed by government servants (18\%). 49\% population were living with spouse and children while $34 \%$ lived in extended families. The participants were from different states of India, majority of them were from Karnataka (52\%) rural areas (52\%) (Table. 1).

The effect of training was assessed using the score based on pre and post test. The score of $0-10$ was seen in $4 \%$ of population while those was reduced to $1 \%$ post test similarly we can seen the rise in score above 40 among post test $(20 \%)$ as compared to pretest $(10 \%)$.

The mean pre and post test score of all participants at $95 \%$ confidence level was $29.26 \pm 3.78$ and $33.78 \pm 4.12$ respectively. The difference between the mean of pre and post test was significantly associated among various groups based on gender, Karnataka, rural and urban, government and salaried, living conditions as well (Table. 2).

The association of demographic variables with the mean KAP score was assessed using Mann Whitney $U$ test and Kruskal Wallis test. The results showed a significant improvement in the KAP score among all the 
Table 1

Socio demographic profile of participants.

\begin{tabular}{|c|c|c|c|}
\hline Variables & & $\begin{array}{l}\text { Number } \\
(2726)\end{array}$ & Percentage \\
\hline \multirow[t]{10}{*}{ State } & Karnataka & 1422 & 52 \\
\hline & West bengal & 247 & 9 \\
\hline & Madhya Pradesh & 189 & 7 \\
\hline & Tamil Nadu, AP & 231 & 9 \\
\hline & Kerala & 172 & 6 \\
\hline & Maharashtra & 105 & 4 \\
\hline & Jaharkhand & 56 & 2 \\
\hline & Chhattisgarh & 71 & 3 \\
\hline & Uttar Pradesh & 70 & 3 \\
\hline & $\begin{array}{l}\text { Bihar, Gujarat, } \\
\text { Uttarkhand, others }\end{array}$ & 163 & 6 \\
\hline Gender & Male & 1636 & 60 \\
\hline Place & Rural & 1418 & 52 \\
\hline \multirow[t]{6}{*}{ Qualification } & Graduates & 1177 & 43 \\
\hline & High school & 137 & 5 \\
\hline & Intermediate/Diploma & 288 & 11 \\
\hline & Middle school & 38 & 1 \\
\hline & PG and above & 1071 & 39 \\
\hline & $\begin{array}{l}\text { Illiterates and Primary } \\
\text { school }\end{array}$ & 30 & 1 \\
\hline \multirow[t]{2}{*}{ Occupation } & Salaried & 1608 & 59 \\
\hline & Government & 518 & 19 \\
\hline \multirow[t]{2}{*}{$\begin{array}{l}\text { Current living } \\
\text { arrangement }\end{array}$} & $\begin{array}{l}\text { Living with spouse and } \\
\text { child }\end{array}$ & 1363 & 50 \\
\hline & Extended family & 927 & 34 \\
\hline
\end{tabular}

Table 2

Comparison of pre and post test among all participants.

\begin{tabular}{lccc}
\hline Total participants & Mean & SD & P value \\
\hline Male & & & \\
Pre test & 26.73 & 4.75 & $<.001$ \\
Post test & 36.45 & 4.62 & \\
Females & 27.69 & 4.02 & \\
Pre test & 37.63 & 3.75 & \\
Post test & & & \\
Karnataka & 28.43 & 4.32 & $<0.01$ \\
Pre test & 35.82 & 4.89 & \\
Post test & & & \\
Rural & 24.67 & 5.67 & \\
Pre test & 34.87 & 5.56 & \\
Post test & & & \\
Urban & 28.48 & 5.87 & \\
Pre test & 38.89 & 5.98 & \\
Post test & & & \\
Salaried & 30.57 & 5.78 & \\
Pre test & 40.67 & 4.67 & \\
Post test & & & \\
Government & 30.37 & 5.67 & \\
Pre test & 41.62 & 4.57 & \\
Post test & 28.67 & 4.89 & \\
Living with spouse and children & & \\
Pre test & 36.54 & & \\
Post test & & & \\
Extended Family & 34.45 & & \\
Pre test & & & \\
Post test & & & \\
\hline
\end{tabular}

demographic profile (Table. 3 ).

The results revealed a positive significant linear correlation between knowledge-attitude $(\mathrm{r}=0.332, \mathrm{p}<0.01)$, Knowledge-practice $(\mathrm{r}=$ $0.245, \mathrm{p}<0.01)$ and attitude-practice $(\mathrm{r}=0.327, \mathrm{p}<0.01)$. This reaffirms the relation between knowledge, attitude and practice to control the spread of COVID19 infection (Table. 4).

Our study showed that regarding spread of COVID 19, post test showed a significant improvement in the knowledge especially regarding droplet (88\%) and fomite (74\%) transmission. Perception of participants regarding Common symptoms of COVID 19 in terms of cough, fever and difficulty breathing was increased by $94 \%$. The
Table 3

Comparison of demographic characteristics with the mean KAP score.

\begin{tabular}{|c|c|c|c|c|c|c|}
\hline \multirow{2}{*}{$\begin{array}{l}\begin{array}{l}\text { Demographic } \\
\text { Characteristics }\end{array} \\
\mathrm{N}=2726\end{array}$} & \multicolumn{2}{|c|}{$\begin{array}{l}\text { Knowledge score } \\
(\text { Mean } \pm \text { SD) }\end{array}$} & \multicolumn{2}{|c|}{$\begin{array}{l}\text { Attitude Score } \\
(\text { Mean } \pm \text { SD) }\end{array}$} & \multicolumn{2}{|c|}{$\begin{array}{l}\text { Practice Score } \\
\text { (Mean } \pm \text { SD) }\end{array}$} \\
\hline & $\begin{array}{l}\text { Pre } \\
\text { test }\end{array}$ & Post & $\begin{array}{l}\text { Pre } \\
\text { test }\end{array}$ & $\begin{array}{l}\text { Post } \\
\text { test }\end{array}$ & $\begin{array}{l}\text { Pre } \\
\text { test }\end{array}$ & $\begin{array}{l}\text { Post } \\
\text { test }\end{array}$ \\
\hline \multicolumn{7}{|l|}{ Age:** } \\
\hline $18-27(634)$ & $\begin{array}{l}12.6 \\
\pm 3.1\end{array}$ & $\begin{array}{l}18.2 \\
\pm 2.6\end{array}$ & $\begin{array}{l}7.6 \pm \\
1.1\end{array}$ & $\begin{array}{l}10.2 \\
\pm 1.6\end{array}$ & $\begin{array}{l}7.6 \\
\pm 1.1\end{array}$ & $\begin{array}{l}8.2 \pm \\
2.6\end{array}$ \\
\hline $28-37(1051)$ & $\begin{array}{l}14.5 \\
\pm 3.8\end{array}$ & $\begin{array}{l}17.9 \\
\pm 3.4\end{array}$ & $\begin{array}{l}6.5 \pm \\
1.6\end{array}$ & $\begin{array}{l}11.9 \\
\pm 1.4\end{array}$ & $\begin{array}{l}4.5 \\
\pm 1.8\end{array}$ & $\begin{array}{l}4.9 \pm \\
3.4\end{array}$ \\
\hline $38-47$ (642) & $\begin{array}{l}14.6 \\
\pm 4.2\end{array}$ & $\begin{array}{l}18.3 \\
\pm 3.2\end{array}$ & $\begin{array}{l}8.6 \pm \\
1.3\end{array}$ & $\begin{array}{l}10.3 \\
\pm 1.6\end{array}$ & $\begin{array}{l}4.6 \\
\pm 2.2\end{array}$ & $\begin{array}{l}8.3 \pm \\
3.2\end{array}$ \\
\hline $48-57(321)$ & $\begin{array}{l}15.2 \\
\pm 3.6\end{array}$ & $\begin{array}{l}19.6 \\
\pm 4.3\end{array}$ & $\begin{array}{l}9.2 \pm \\
1.6\end{array}$ & $\begin{array}{l}11.6 \\
\pm 1.3\end{array}$ & $\begin{array}{l}5.2 \\
\pm 3.6\end{array}$ & $\begin{array}{l}9.6 \pm \\
0.3\end{array}$ \\
\hline $58-67(74)$ & $\begin{array}{l}12.7 \\
\pm 3.7\end{array}$ & $\begin{array}{l}19.4 \\
\pm 3.8\end{array}$ & $\begin{array}{l}8.7 \pm \\
1.7\end{array}$ & $\begin{array}{l}11.4 \\
\pm 1.8\end{array}$ & $\begin{array}{l}2.7 \\
\pm 3.7\end{array}$ & $\begin{array}{l}9.4 \pm \\
0.8\end{array}$ \\
\hline$>67(4)$ & $\begin{array}{l}15.2 \\
\pm 3.9\end{array}$ & $\begin{array}{l}18.6 \\
\pm 4.7\end{array}$ & $\begin{array}{l}9.2 \pm \\
1.9\end{array}$ & $\begin{array}{l}10.6 \\
\pm 1.7\end{array}$ & $\begin{array}{l}5.2 \\
\pm 3.9\end{array}$ & $\begin{array}{l}8.6 \pm \\
2.7\end{array}$ \\
\hline \multicolumn{7}{|l|}{ Sex* } \\
\hline Male (1636) & $\begin{array}{l}14.7 \\
\pm 2.4\end{array}$ & $\begin{array}{l}18.7 \\
\pm 1.6\end{array}$ & $\begin{array}{l}8.5 \pm \\
1.5\end{array}$ & $\begin{array}{l}11.7 \\
\pm 1.4\end{array}$ & $\begin{array}{l}5.7 \\
\pm 1.8\end{array}$ & $\begin{array}{l}6.7 \pm \\
1.7\end{array}$ \\
\hline Female (1090) & $\begin{array}{l}15.2 \\
\pm 2.9 \\
\end{array}$ & $\begin{array}{l}19.2 \\
\pm 1.9 \\
\end{array}$ & $\begin{array}{l}7.2 \pm \\
1.9\end{array}$ & $\begin{array}{l}12.2 \\
\pm 1.9 \\
\end{array}$ & $\begin{array}{l}7.2 \\
\pm 1.4 \\
\end{array}$ & $\begin{array}{l}8.2 \pm \\
1.9\end{array}$ \\
\hline \multicolumn{7}{|l|}{ Address: * } \\
\hline Urban (1308) & $\begin{array}{l}15.7 \\
\pm 1.8\end{array}$ & $\begin{array}{l}19.7 \\
\pm 1.7\end{array}$ & $\begin{array}{l}7.5 \pm \\
1.4\end{array}$ & $\begin{array}{l}9.7 \pm \\
1.8\end{array}$ & $\begin{array}{l}4.7 \\
\pm 1.3\end{array}$ & $\begin{array}{l}5.7 \pm \\
1.7\end{array}$ \\
\hline Rural (1418) & $\begin{array}{l}11.2 \\
\pm 1.9\end{array}$ & $\begin{array}{l}15.2 \\
\pm 1.9\end{array}$ & $\begin{array}{l}3.2 \pm \\
1.8\end{array}$ & $\begin{array}{l}7.2 \pm \\
1.7\end{array}$ & $\begin{array}{l}3.2 \\
\pm 1.7\end{array}$ & $\begin{array}{l}7.2 \pm \\
1.8\end{array}$ \\
\hline \multicolumn{7}{|l|}{ Education** } \\
\hline Illiterate (10) & $\begin{array}{l}4.7 \pm \\
1.1\end{array}$ & $\begin{array}{l}8.7 \pm \\
1.6\end{array}$ & $\begin{array}{l}7.6 \pm \\
1.1\end{array}$ & $\begin{array}{l}11.2 \\
\pm 1.5\end{array}$ & $\begin{array}{l}5.4 \\
\pm 1.3\end{array}$ & $\begin{array}{l}7.3 \pm \\
1.6\end{array}$ \\
\hline $\begin{array}{l}\text { Primary Middle } \\
\text { School (20) }\end{array}$ & $\begin{array}{l}4.5 \pm \\
1.7\end{array}$ & $\begin{array}{l}7.9 \pm \\
1.8\end{array}$ & $\begin{array}{l}7.4 \pm \\
1.6\end{array}$ & $\begin{array}{l}11.5 \\
\pm 1.4\end{array}$ & $\begin{array}{l}4.6 \\
\pm 1.5\end{array}$ & $\begin{array}{l}6.8 \pm \\
1.6\end{array}$ \\
\hline High School (137) & $\begin{array}{l}8.2 \pm \\
2.6\end{array}$ & $\begin{array}{l}9.6 \pm \\
1.3\end{array}$ & $\begin{array}{l}7.6 \pm \\
1.3\end{array}$ & $\begin{array}{l}10.3 \\
\pm 1.6\end{array}$ & $\begin{array}{l}6.4 \\
\pm 1.4\end{array}$ & $\begin{array}{l}8.7 \pm \\
1.6\end{array}$ \\
\hline Intermediate & $\begin{array}{l}11.7 \\
\pm 2.7\end{array}$ & $\begin{array}{l}13.4 \\
\pm 2.8\end{array}$ & $\begin{array}{l}9.2 \pm \\
1.6\end{array}$ & $\begin{array}{l}11.6 \\
\pm 1.3\end{array}$ & $\begin{array}{l}6.1 \\
\pm 1.2\end{array}$ & $\begin{array}{l}9.7 \pm \\
1.1\end{array}$ \\
\hline Graduate (1177) & $\begin{array}{l}10.2 \\
\pm 2.3\end{array}$ & $\begin{array}{l}15.6 \\
\pm 3.7\end{array}$ & $\begin{array}{l}8.7 \pm \\
1.7\end{array}$ & $\begin{array}{l}11.4 \\
\pm 1.8\end{array}$ & $\begin{array}{l}5.7 \\
\pm 2.7\end{array}$ & $\begin{array}{l}8.2 \pm \\
1.7\end{array}$ \\
\hline $\begin{array}{l}\text { Post graduate } \\
\text { (1071) }\end{array}$ & $\begin{array}{l}13.7 \\
\pm 2.7 \\
15.2 \\
\pm 3.9 \\
\end{array}$ & $\begin{array}{l}16.7 \\
\pm 1.7 \\
16.8 \\
\pm 1.9\end{array}$ & $\begin{array}{l}9.2 \pm \\
1.9 \\
12.7 \\
\pm 3.7\end{array}$ & $\begin{array}{l}10.6 \\
\pm 1.7 \\
12.7 \\
\pm 3.7\end{array}$ & $\begin{array}{l}7.2 \\
\pm 1.4 \\
8.7 \\
\pm 1.6\end{array}$ & $\begin{array}{l}8.4 \pm \\
1.3 \\
9.1 \pm \\
0.7\end{array}$ \\
\hline \multicolumn{7}{|l|}{ Occupation* } \\
\hline Unemployed (156) & $\begin{array}{l}7.6 \pm \\
3.1\end{array}$ & $\begin{array}{l}11.2 \\
\pm 2.6\end{array}$ & $\begin{array}{l}8.2 \pm \\
1.7\end{array}$ & $\begin{array}{l}11.3 \\
\pm 1.8\end{array}$ & $\begin{array}{l}7.6 \\
\pm 1.1\end{array}$ & $\begin{array}{l}8.2 \pm \\
2.6\end{array}$ \\
\hline Housewife (235) & $\begin{array}{l}6.5 \pm \\
3.8\end{array}$ & $\begin{array}{l}17.9 \\
\pm 3.4\end{array}$ & $\begin{array}{l}5.4 \pm \\
1.6\end{array}$ & $\begin{array}{l}10.9 \\
\pm 1.6\end{array}$ & $\begin{array}{l}4.3 \\
\pm 3.8\end{array}$ & $\begin{array}{l}7.9 \pm \\
1.4\end{array}$ \\
\hline $\begin{array}{l}\text { Self employed } \\
\text { (100) }\end{array}$ & $\begin{array}{l}14.6 \\
\pm 4.2\end{array}$ & $\begin{array}{l}18.3 \\
\pm 3.2\end{array}$ & $\begin{array}{l}7.6 \pm \\
2.3\end{array}$ & $\begin{array}{l}12.4 \\
\pm 1.6\end{array}$ & $\begin{array}{l}6.6 \\
\pm 3.1\end{array}$ & $\begin{array}{l}8.3 \pm \\
1.2\end{array}$ \\
\hline Salaried (1608) & $\begin{array}{l}15.2 \\
\pm 3.6\end{array}$ & $\begin{array}{l}19.6 \\
\pm 4.3\end{array}$ & $\begin{array}{l}9.8 \pm \\
1.6\end{array}$ & $\begin{array}{l}10.6 \\
\pm 1.8\end{array}$ & $\begin{array}{l}6.4 \\
\pm 2.6\end{array}$ & $\begin{array}{l}9.6 \pm \\
0.2\end{array}$ \\
\hline Daily wage (109) & $\begin{array}{l}12.7 \\
\pm 3.7\end{array}$ & $\begin{array}{l}19.4 \\
\pm 3.8\end{array}$ & $\begin{array}{l}5.7 \pm \\
1.7\end{array}$ & $\begin{array}{l}10.4 \\
\pm 1.6\end{array}$ & $\begin{array}{l}7.4 \\
\pm 2.7\end{array}$ & $\begin{array}{l}9.2 \pm \\
0.8\end{array}$ \\
\hline Govt (518) & $\begin{array}{l}15.2 \\
\pm 3.9\end{array}$ & $\begin{array}{l}18.6 \\
\pm 4.7\end{array}$ & $\begin{array}{l}7.2 \pm \\
1.9\end{array}$ & $\begin{array}{l}9.6 \pm \\
1.7\end{array}$ & $\begin{array}{l}5.1 \\
\pm 2.9\end{array}$ & $\begin{array}{l}8.6 \pm \\
4.7\end{array}$ \\
\hline
\end{tabular}

Note: * Mann Whitney $U$ test and **Kruskal Wallis test were used to check the association. $\mathrm{P}$ value $<0.05$ was considered significant.

Table 4

Correlation between knowledge, attitude and practices post test.

\begin{tabular}{lll}
\hline Variable & Correlation coefficient & P value \\
\hline Knowledge-Attitude & $\mathbf{0 . 3 3 2}$ & $<0.01$ \\
Knowledge-Practice & 0.245 & $<0.01$ \\
Attitude-Practice & $\mathbf{0 . 3 2 7}$ & $<0.01$ \\
\hline
\end{tabular}

prevention of COVID 19 by preventing crowded places (92\%) and following Social distancing Mask and Sanitization (SMS) was improved sufficiently by training. Pre training only $64 \%$ individuals thought there is no licensed drug for COVID treatment which increased significantly 
$86 \%$ post training. $62 \%$ individuals thought holding breath without discomfort as an indication of COVID diagnosis pre training, while it reduced significantly post training (24\%). Around 50\% people thought hot and humid temperature protects from COVID 19. The most reliable source of information for COVID 19 was government websites followed by newspaper and news channel. Practices followed by individuals to boost their immunity were exercise and home remedies while only minor (16\%) population thought quitting smoking and alcohol can boost immunity.

\section{Discussion}

The present study assessed impact of health literacy among 2726 participants conducting 259 webinar sessions across India. The study showed a significant increase in knowledge score of the individual the rise in score above 40 among post test (20\%) as compared to pretest (10\%). The results are comparable with the similar findings conducted by Shrivastava et al. which showed pre and post test were effective way of assessing as well as creating awareness among the participants. ${ }^{11}$

In the present study the pre test and post test scores of the participants at confidence interval of $95 \%$ were 29.26 and 33.78 respectively and the difference was statistically significant among various groups of based on gender, state, rural and urban, working conditions like government, salaried and also on living conditions. The findings were similar to studies carried out by Shrivastava et al. and Chan which demonstrated a significant difference in the mean scores of pre and post test. ${ }^{12}$

The present study revealed that the scores of knowledge scores in terms of epidemiology and prevention of COVID 19 in terms of following safety recommendation was significantly increased post test after the training. The highest difference was observed in the mode of spread of infection and usage of type of mask by the individual. The findings are comparable with the study carried out by Bhagvathula et al. which revealed that majority of participants were aware of safety recommendations. ${ }^{13}$ If more knowledge is provided to general population regarding mode of transmission and ways to protect oneself from combating the disease could help in controlling the disease.

Some of the myths associated with COVID 19 among Indian population were holding of breath test to assess the lung capacity, consumption of alcohol for cure of COVID 19, increased immunity during youth age group were seen higher during pre test which is stated by World Health organization. ${ }^{14}$ The Most reliable and effective tool to debunk these myths are by health literacy.

\section{Conclusion}

Covid 19 era have brought a tremendous changes in the lifestyle globally. Social Distance, Mask and Sanitization (SMS) have become the new norm. Health literacy plays a crucial role in educating the population regarding the evolving science of COVID 19.

\section{Funding}

None.

\section{Declaration of competing interest}

None declared.

\section{Acknowledgment}

We would like to thank the entire team of CSR for organizing webinar across India. It's a pleasure to extend our gratitude to Shikshana, Dhan foundation, Grameena Koota and various NGO involved during the sessions. Lastly we thank all the participants without whom the research wouldn't be possible.

\section{References}

1 Zhou P, Yang XL, Wang XG, et al. A pneumonia outbreak associated with a new coronavirus of probable bat origin. Nature. 2020;579(7798):270-273.

2 WHO Director-General's Opening Remarks at the Media Briefing on COVID-19. 11 March 2020.

3 COVID-19 coronavirus pandemic worldometer. https://www.worldometers.info/ coronavirus/?utm_campaign =homeAdvegas 1 ? $\% 22 \% 20 \% 5 \mathrm{Cl} \% 22$ countries. Published June 2020. Assessed on August 2020.

4 Modes of transmission of virus causing COVID-19: implications for IPC precaution recommendations Scientific brief. https://www.who.int/news-room/commentari es/detail/modes-of-transmission-of-virus-causing-covid-19-implications-for-ipc-pr ecaution-recommendations; 29 March 2020.

5 Gettleman Jeffrey, Schultz Kai. Modi Orders 3-Week Total Lockdown for All 1.3 Billion Indians. The New York Times; 24 March 2020, 0362-4331.

6 https://www.statista.com/statistics/1104709/coronavirus-deaths-worldwide-per-mi llion-inhabitant; 2020. Accessed April , 2020.

7 Detail question and answer on COVID 19 for public. https://www.mohfw.gov. Accessed April , 2020.

8 Revised strategy of COVID19 testing in India (Version 3, dated 20/03/2020), indian council of medical research department of health research. https://www.icmr.gov. in/pdf/covid/strategy/2020-03-20 covid19 test v3.pdf.

9 About COVID 19. https://www.cdc.gov/coronavirus/2019-ncov/your-health/abo ut-covid-19.html. Accessed April , 2020.

10 COVID 19 India. https://www.covid19india.org/state/TT. Accessed April , 2020.

11 Shrivastava M, Shah N, Navaid S. Assessment of change in knowledge about research methods among delegates attending research methodology workshop. Perspect Clin Res. 2018;9(2):83.

12 Chan CH, Chan TN, Yuen MC, Tung WK. Evaluation of a simulation-based workshop on clinical performance for emergency physicians and nurses. World J Emerg Med. 2015;6(1):16.

13 Modi PD, Nair G, Uppe A, et al. COVID-19 awareness among healthcare students and professionals in Mumbai metropolitan region: a questionnaire-based survey. Cureus. 2020;12(4).

14 Coronavirus disease (COVID-19) advice for the public: Mythbusters. https://www. who.int/emergencies/diseases/novel-coronavirus-2019/advice-for-public/mythbusters. Accessed April , 2020. 